This item was submitted to Loughborough's Research Repository by the author.

Items in Figshare are protected by copyright, with all rights reserved, unless otherwise indicated.

\title{
Modelling variable glacier lapse rates using ERA-Interim reanalysis climatology: an evaluation at Vestari- Hagafellsjökull, Langjökull, Iceland
}

PLEASE CITE THE PUBLISHED VERSION

http://dx.doi.org/10.1002/joc.3440

PUBLISHER

Wiley (C Royal Meteorological Society

VERSION

AM (Accepted Manuscript)

LICENCE

CC BY-NC-ND 4.0

\section{REPOSITORY RECORD}

Hodgkins, Richard, S. Carr, F. Palsson, S. Gumundsson, and H. Bjornsson. 2019. "Modelling Variable Glacier Lapse Rates Using Era-interim Reanalysis Climatology: An Evaluation at Vestari- Hagafellsjökull, Langjökull, Iceland". figshare. https://hdl.handle.net/2134/12979. 
This item was submitted to Loughborough's Institutional Repository (https://dspace.lboro.ac.uk/) by the author and is made available under the following Creative Commons Licence conditions.

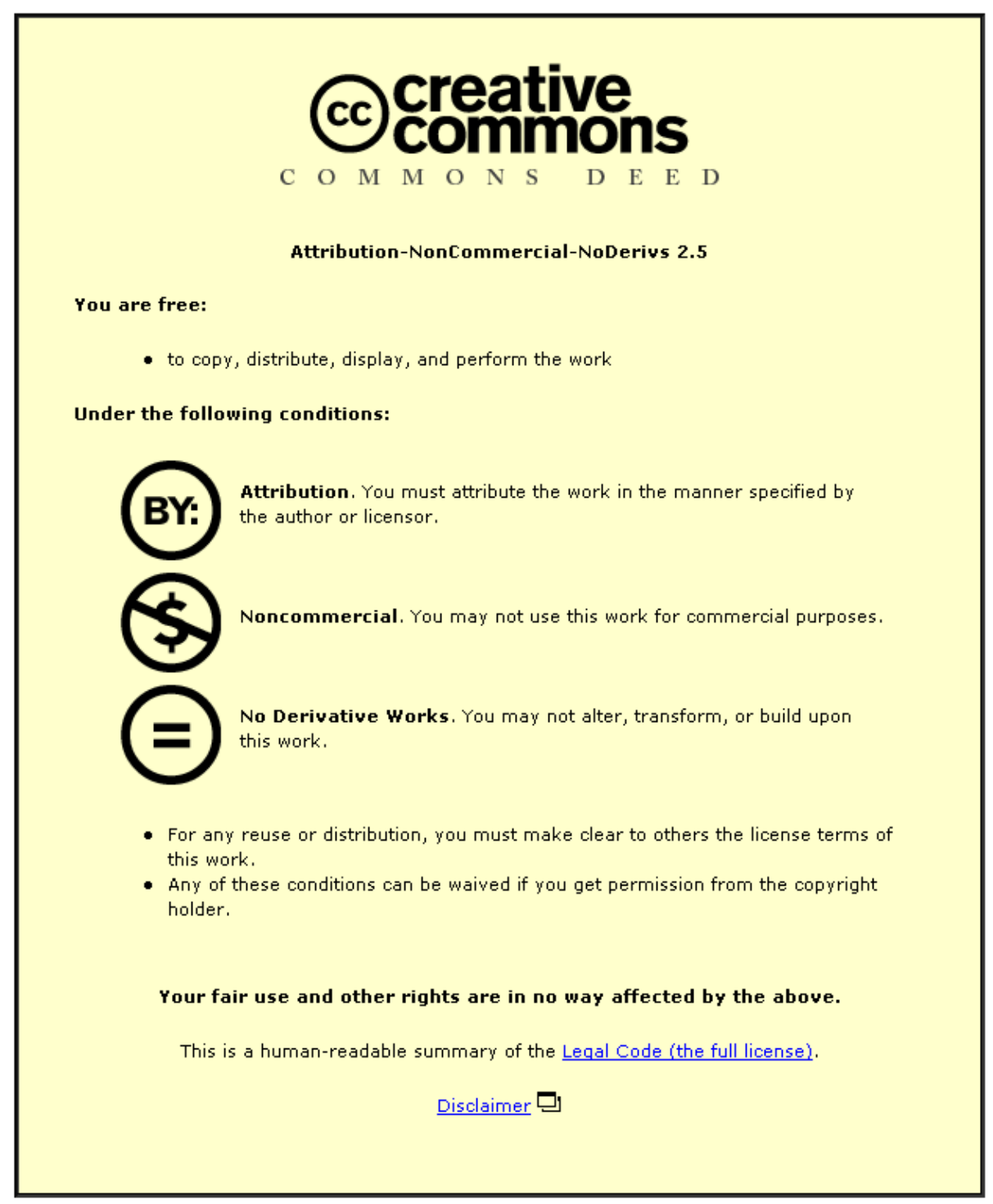

For the full text of this licence, please go to: http://creativecommons.org/licenses/by-nc-nd/2.5/ 
Modelling variable glacier lapse rates using ERA-Interim reanalysis climatology: an evaluation at Vestari-Hagafellsjökull, Langjökull, Iceland

\author{
R. Hodgkins ${ }^{1}$, S. Carr², F. Pálsson ${ }^{3}$, S. Guð̋mundsson ${ }^{3}$, H. Björnsson ${ }^{3}$. \\ ${ }^{1}$ Department of Geography, Loughborough University, Leicestershire LE11 \\ 3TU, U.K. \\ ${ }^{2}$ Department of Geography, Queen Mary University of London, London E1 4NS, \\ U.K. \\ ${ }^{3}$ Institute of Earth Sciences, University of Iceland, Sturlugata 7, 101 Reykjavík, \\ Iceland.
}

Short title: Variable lapse rate modelling, Langjökull, Iceland 


\section{Abstract}

The near-surface air temperature lapse rate is an important tool for spatiallydistributing temperatures in snow- and ice-melt models, but is difficult to parameterize, as it is not simply correlated with boundary-layer meteorological variables, such as temperature itself. This contribution quantifies spring-autumn lapse-rate variability over five years at Vestari-Hagafellsjökull, a southerly outlet of Langjökull in Iceland. It is observed that summer lapse rates $\left(0.57^{\circ} \mathrm{C} 100 \mathrm{~m}^{-}\right.$ $\left.{ }^{1}\right)$ are significantly lower than non-summer rates, and are also lower than the Saturated Adiabatic Lapse Rate (SALR), which is often adopted in melt models. This is consistent with reduced near-surface temperature sensitivity to freeatmosphere temperature change during the occurrence of melting. A Variable Lapse Rate (VLR) regression model is calibrated with standardized, $750 \mathrm{hPa}$ temperature anomalies derived from ERA-Interim climatology, which is shown to be highly-significantly correlated with near-surface temperatures. The modeled VLR overestimates cumulative June-September Positive Degree Days (PDDs) by $3 \%$ when used to extrapolate temperatures from 1100 to $500 \mathrm{~m}$ a.s.l. on the glacier, whereas the SALR over-estimates cumulative PDDs by $14 \%$. ERA-Interim data therefore appear to offer a good representation of freeatmosphere temperature variability over Vestari-Hagafellsjökull, and the modelling approach offers a simple means of improving lapse-rate parameterizations in melt models.

Key words: air temperature; lapse rate; Automatic Weather Station; ERAInterim; glacier; Langjökull; Iceland 


\section{Introduction}

In glacier-melt modeling, and regardless of whether an energy-balance or a temperature-index/degree-day approach is taken, it is typically necessary to allow for spatial variation in air temperature (hereafter simply temperature), unless running a regional climate model, which is often not justified in terms of spatial resolution and computing effort. This is a common issue whether upscaling from in-situ, point measurements - typically from Automatic Weather Stations (AWS), often at low elevation - or downscaling from gridded, reanalysis climatology data with spatial resolutions of 10 s or $100 \mathrm{~s}$ of $\mathrm{km}$. A simple but effective tool in either case is the lapse rate. Following Gardner et al. (2009), the lapse rate is here defined as the decrease in near-surface temperature with elevation along the glacier surface, positive when temperature decreases as elevation increases.

Most often the free-air, Saturated Adiabatic Lapse Rate (SALR), $0.6-0.7^{\circ} \mathrm{C} 100$ $\mathrm{m}^{-1}$ (Seidel and Free, 2003), is applied (e.g. Glover, 1999; Thomas et al., 2003; de Woul et al., 2006), although a range of studies (e.g. Greuell and Böhm, 1998; Braun and Hock, 2004; Hanna et al., 2005; Klok et al., 2005; Marshall et al., 2007; Gardner and Sharp, 2009; Gardner et al., 2009) has now shown that lapse rates measured over melting glacier surfaces tend to be lower than freeair values, mainly as a result of the temperature over melting snow and ice surfaces remaining close to $0^{\circ} \mathrm{C}$. Sensible-heat exchange with the glacier surface appears to offset adiabatic warming of katabatic airflow (Greuell et al., 1997; Greuell and Böhm, 1998). Use of the SALR is often unavoidable, as 
temperature measurements at multiple elevations on glaciers remain the exception rather than the norm, but clearly, upscaling or downscaling temperatures with unrepresentative lapse rates will lead to potentially significant errors in estimated temperatures, and in melt rates determined from them by energy-balance or temperature-index approaches.

Reliance on the SALR has largely been necessitated by the difficulty in finding a simple and effective way to predict lapse rates. For example, Konya et al. (2007) found no significant correlation between lapse rate and any meteorological variables they studied at Storglaciären, Sweden, despite stratifying data according to wind direction and precipitation occurrence to allow for the influence of contrasting synoptic conditions. They concluded that there was no simple way to parameterize lapse rates for melt modeling, and that temperature measurements at multiple elevations were required to characterize lapse rates adequately. Braun and Hock (2004) found lower-than-average lapse rates during periods of rapid melt associated with warm, humid air advection at King George Island, Antarctica, and higher-than-average rates during periods of slow melt coinciding with cold air advection. Likewise, Marshall et al. (2007) found that summer and autumn lapse rates were steep in the presence of strong cyclonic circulation over the Prince of Wales Icefield, Canada, whereas shallow lapse rates and boundary-layer temperature inversions typified periods of anticyclonic circulation. However, Marshall et al. (2007) also found that daily lapse-rate variations did not correlate simply with any available synoptic-scale or surface meteorological variable overall, despite these general associations. 
Probably the most successful attempt to model lapse rates for glacier melt studies so far is that of Gardner et al. (2009), who discovered a strong, negative relationship between measured lapse rates and variability in free-atmospheric temperatures extracted from U.S. National Center for Environmental Protection (NCEP) North American Regional Reanalysis (NARR) data, for multi-year temperature series from various transects over Canadian high-Arctic ice masses. This relationship was used to develop simple regression models predicting lapse rates from daily, standardized anomalies in $750 \mathrm{hPa}$ re-analysis temperature. The predictions from these models not only yielded significant reductions in error in calculated Positive Degree-Days (PDDs) compared to those using the SALR, but also provide an empirical method for generating temporally-variable lapse-rate values. While the method is in principle transferrable, regression coefficients were found to vary somewhat from ice mass to ice mass, such that Gardner et al. (2009) recommended that lapse-rate models should be calibrated for individual glaciers.

\section{Aims}

The aims of this contribution are, first, to determine lapse rates at VestariHagafellsjökull, an outlet of Langjökull, Iceland, from 5-years' AWS temperature data. Monthly lapse-rate variability will then be analyzed for each year for the spring-to-autumn period. Thereafter, a regression-based model for simulating temporally-variable lapse rates (Gardner et al., 2009) will be calibrated with the AWS data and with ERA-Interim re-analysis data. The model will then be 
validated by evaluating its performance in predicting temperatures and Positive Degree Days (PDDs) in comparison to the SALR and an uncalibrated version of the model. Conclusions will finally be drawn regarding the seasonal variability of lapse rates at Vestari-Hagafellsjökull, and on the transferability of the variable lapse-rate model approach.

\section{Location}

Situated in west-central Iceland, Langjökull is that country's second-largest ice cap, at c. $925 \mathrm{~km}^{2}$ (Fig. 1). The focus of this study is Vestari-Hagafellsjökull, one of two major outlet lobes at the southerly margin of the ice cap (Fig. 1): extending from $64.48-64.68^{\circ} \mathrm{N}, 20.23-20.53^{\circ} \mathrm{W}$, it is $157 \mathrm{~km}^{2}$ in area, with an altitude range of c. 470-1440 m a.s.I. Jónsdóttir (2008) estimates an annual runoff of $5,000-10,000 \mathrm{~mm} \mathrm{a}^{-1}$ around the southern margin of Langjökull: meltwater from Vestari-Hagafellsjökull feeds the Hvítá river, although a significant proportion is diverted to groundwater (Sigurðsson, 1990), ultimately supplying the city of Reykjavík. According to Björnsson et al. (2002), the net mass balance of Langjökull was negative over the period 1996-2001, and the accumulation area ratio varied from $0.1-0.4$; the total mass loss in this period was $5.73 \mathrm{~m}$ w.e. $\left(5.36 \mathrm{~km}^{3}\right.$ w.e.), or about $3 \%$ of the total ice mass. Since the late '90s, the balance of southern dome of Langjökull, which VestariHagafellsjökull drains, has also been negative, with values of $-1.08 \mathrm{~m}$ w.e. (2006), -1.41 m w.e. (2007) (WGMS, 2009), -1.84 m w.e. (2008) and -0.36 m w.e. (2009) (http://www.wgms.ch/mbb/sum09.html) having been determined. The steady-state ELA of the southern dome is $975 \mathrm{~m}$ a.s.l. (WGMS, 2009), 
although the observed ELA is typically somewhat higher, given the prevailing negative balance. Pope et al. (2009) determined a net balance from DEM comparison of $-3.23 \mathrm{~m}$ w.e. $\mathrm{a}^{-1}$ for Vestari-Hagafellsjökull itself for the period 1997-2007, with the annual rate of mass loss increasing during the period.

\section{Data sources}

Near-surface temperatures were obtained for the spring-autumn (AprilOctober) period each year from 2003-2007 from AWS located on VestariHagafellsjökull: up to four were installed on the glacier at one time, although for the majority of the period two were present. The AWS were based on tripods or quadropods, and stood freely on the glacier surface, with instruments at a nominal height of $2 \mathrm{~m}$ and in a parallel plane to the surface. Temperature was measured at each with Vaisala HMP45C sensors located within URS1 radiation shields. The precision of these measurements is $\pm 0.3^{\circ} \mathrm{C}$ at $0^{\circ} \mathrm{C}$ and $\pm 0.4^{\circ} \mathrm{C}$ at $-20^{\circ} \mathrm{C}$. Diminished long-term accuracy due to sensor drift and deterioration is minimized as the AWS were removed each autumn and the sensors recalibrated (Guðmundsson et al., 2009). Temperature data were recorded at 1060-minute intervals and post-processed to 6-hourly or daily averages, as required. Monthly mean temperatures at the lowermost and uppermost AWS elevations on the glacier are summarized in Table 1: for the great majority of cases, and for all the summer period which is the subject of lapse-rate modelling described below, these correspond to 500 and $1100 \mathrm{~m}$ a.s.l., covering about $65 \%$ of the elevation range of the glacier. In Table 1 , only months for which sufficient data are available to calculate lapse rates are 
presented; these mostly span the period from May to October. Lapse-rates themselves, calculated from 6-hourly temperature data, are presented in Table 2. The Icelandic spring is only two months long (April and May), as is the autumn (October and November); the summer is defined as June to September (Hanna et al., 2004). This dataset therefore constitutes a complete, five-year record of summer lapse rates for Vestari-Hagafellsjökull.

Gardner et al. (2009) used NARR temperatures from the $750 \mathrm{hPa}$ atmospheric level to represent free-air temperatures at an elevation several hundred meters above the glacier surface. These temperatures affect near-surface lapse rates directly by modifying the sensible heat flux between the surface and atmosphere; they may influence the radiative fluxes indirectly through their contribution to changing surface albedo. Free-air temperatures in this study are derived from European Centre for Medium-range Weather Forecasts (ECMWF) ERA-Interim data. This is a re-analysis of the atmospheric state covering the period from 1989 up to the present, using T255 (80 km) horizontal resolution, boundary forcing fields from ECMWF operations, and a 4D-Var data assimilation system which finds the 12-hour forecast evolution that optimally fits available observations (ECMWF, 2006, 2007, 2008). 6-hourly temperatures at 700,750 and $800 \mathrm{hPa}$ atmospheric levels from the c. $110 \times 50 \mathrm{~km}$ grid cell in which Vestari-Hagafellsjökull is located were downloaded from ERA-Interim daily fields (http://data-portal.ecmwf.int/data/d/interim_daily/) for periods corresponding to the AWS measurements described above. Given the relative dimensions of the glacier and the grid cell, any averaging of temperatures from 
adjoining cells was deemed superfluous.

To ensure that the reanalysis data provide a valid representation of temperature variability over the glacier, temperatures from the three pressure levels 700,750 and $800 \mathrm{hPa}$ were correlated with AWS temperatures, following detrending by subtraction of monthly means: results are presented in Table 3. The small spatial separation between AWS (maximum less than $3 \mathrm{~km}$ east-west, less than $11 \mathrm{~km}$ north-south; Fig. 1), means that it is unlikely that each will be influenced by different air masses at any one time, so no further data treatment was deemed necessary. Pearson product-moment correlation coefficients ranged from $0.57-0.85$, and were highly significant $(p<0.001)$. The value of the correlations declined slowly from 800 to $700 \mathrm{hPa}$ (Table 3): temperatures from the $750 \mathrm{hPa}$ level provided the best balance between correlation value (which decreased with altitude) and effective representation of free-air variability (which increased with altitude). The mean air pressure recorded at $1100 \mathrm{~m}$ a.s.I. on Vestari-Hagafellsjökull in the measurement period was $880 \mathrm{hPa}$ (not adjusted to sea level), with a range of 831-909 $\mathrm{hPa}$. It therefore appears that ERA-Interim $750 \mathrm{hPa}$ data do indeed provide a valid representation of temperature variability over the glacier.

\section{Temperature and lapse-rate variability}

Temperature time series measured at 500 and $1100 \mathrm{~m}$ a.s.l., and derived from ERA-Interim climatology for the $750 \mathrm{hPa}$ atmospheric level, are shown in Fig 2, for the interval April-October in each of the years 2003-7. The corresponding 
lapse rates for the same time intervals are depicted in Fig. 3. It is apparent from this figure that temperature inversions are brief and infrequent over the glacier, at least for the spring-autumn period. Although the duration of measurements is slightly different each year, it is clear that lapse rates generally decrease during summer, though day-to-day variability remains (standard deviation of summer daily lapse rates varies from $0.19-0.28^{\circ} \mathrm{C}$ : Table 2$)$. Even more apparent is that the lapse rate is below the SALR value (shown on Fig. 3 at $0.65^{\circ} \mathrm{C} 100 \mathrm{~m}^{-1}$ ) for much of the time, particularly during summer.

Mean monthly, near-surface temperatures and lapse rates, determined from the data in Figs. 2 and 3, are presented in Fig. 4, along with their standard deviations. It is evident that June and July temperatures at both elevations, though particularly at $500 \mathrm{~m}$ a.s.l., are rather consistent from year-to-year (Fig. $4(\mathrm{~A})$ and $(\mathrm{C}))$, as reflected in the sharp decline of monthly temperature standard deviations in early summer (Fig. 4 (B) and (D)). Temperature variability increases again in August and September at both elevations. Mean monthly temperatures are positive in June, July and August for all years even at 1100 m a.s.I. (Fig. 4 (C)). September appears to be more of a transitional month, but is generally regarded as part of the melt season, as temperatures at $500 \mathrm{~m}$ a.s.I. remain uniformly positive then, while in two of the five years considered they are also positive at $1100 \mathrm{~m}$ a.s.I.

The summer decrease in lapse rates is shown clearly in Fig. 4 (E). The JuneAugust mean lapse rate across all years is $0.53 \pm 0.05^{\circ} \mathrm{C} 100 \mathrm{~m}^{-1}$ (mean 
Istandard deviation, this format is used throughout); for June-September, it is $0.57 \pm 0.09^{\circ} \mathrm{C} 100 \mathrm{~m}^{-1}$. The mean lapse-rate across all years for non-summer months (April, May and October) is $0.70 \pm 0.07^{\circ} \mathrm{C} 100 \mathrm{~m}^{-1}$. This summer lapserate decrease is highly statistically-significant, as confirmed by comparing means with Student's t-test $($ mean difference $=0.127$, degrees of freedom $(d f)=$ $729, t=7.84, p<0.001)$. The non-summer lapse rate, as far as can be discerned from limited spring and autumn data (9 months across 5 years: Table 2 ), therefore appears to be insignificantly different from the SALR in this location. The summer lapse rate on the other hand, particularly for the warmest three months June-August (15 months across 5 years: Table 2), is statisticallysignificantly lower than the free-air SALR. Notwithstanding Langjökull's location between $64^{\circ}$ and $65^{\circ} \mathrm{N}$, these rates are consistent with previously-published values for Arctic glaciers and the Greenland Ice Sheet summarized in Gardner et al. (2009: Table 1), and similar to the $0.53^{\circ} \mathrm{C} 100 \mathrm{~m}^{-1}$ value for Sátujökull, Iceland, obtained by Jóhanneson et al. (1995) through degree-day model calibration. Unlike the temperatures themselves, there is no clear pattern in lapse-rate standard deviations (Fig. 4(F)).

There is appreciable spatial coherence in temperatures at VestariHagafellsjökull, indicated by consistently, highly-significant correlations between measurements acquired at AWS between 500-1100 m a.s.I. (Table 3): following detrending (by subtraction of monthly means), correlation coefficients of $r=$ $0.63-0.95(p<0.001)$ are obtained. This coherence extends to the freeatmospheric temperatures at the $700-800 \mathrm{hPa}$ levels, as noted above (Section 
4). The association between monthly mean $750 \mathrm{hPa}$ temperatures and lapse rates was also assessed by correlation, as a simple measure of air-mass influence (Table 4): in three of the five years 2003-7, a significant $(p<0.05)$, negative correlation was obtained, though in only one of these years was this highly significant. Moreover, in the other two years, there was no significant correlation between lapse rate and $750 \mathrm{hPa}$ temperature. These results suggest that lower lapse rates are mostly associated with warmer air masses, although the statistical relationship might be stronger if more non-summer data were also included: the two years without a significant correlation are the two years with least non-summer data.

\section{Modeling near-surface temperatures with variable lapse rates}

Having established that free-air temperatures, represented by temperatures derived from reanalysis pressure levels, were significantly correlated with nearsurface temperatures over several Canadian high-Arctic icefields (as is also the case here: Table 3), Gardner et al. (2009) presented a regression-based approach to predicting mean daily lapse rates from reanalysis temperature.

Observed lapse rate for a calibration period is regressed on standardized anomalies in reanalysis temperature; Gardner et al. (2009) considered the 750 $\mathrm{hPa}$-level temperature provided a good representation of free-air temperatures above the glacier boundary layer. Standardization is achieved by subtracting the mean temperature for the interval in question and dividing by its standard deviation. As the regression uses reanalysis temperature standardized anomalies - with zero mean - as the independent variable, model intercepts 
are equivalent to mean summer lapse rates.

In this section, the same approach is applied to the data for VestariHagafellsjökull, in order to evaluate its transferability to a lower-latitude ice mass in a different climatic setting. Gardner et al. (2009) noted that lapse-rate regression model coefficients weren't constant: slopes were relatively consistent, but intercepts - representing lapse rates themselves - varied considerably from glacier to glacier. They therefore suggested that lapse rate models should be calibrated for individual glaciers, and proposed coefficients for Arctic glaciers without sufficient calibration measurements: slope $(m)=$ $-0.11^{\circ} \mathrm{C} 100 \mathrm{~m}^{-1}$ and intercept (lapse rate, $\left.\beta\right)=0.49^{\circ} \mathrm{C} 100 \mathrm{~m}^{-1}$. The results in Sections 4 and 5 suggest that near-surface and ERA-Interim temperatures are significantly associated, while lapse rates and ERA-Interim temperatures are, at least, mostly associated. Therefore there are grounds for anticipating that regressing lapse rates on ERA-Interim $750 \mathrm{hPa}$ standardized anomalies could generate valid model coefficients for Vestari-Hagafellsjökull.

The next step was therefore to estimate regression model coefficients for the June-September intervals of each of the five years 2003-7: coefficients for each year were estimated using data from the other four years for calibration, so that an ensemble of coefficients was generated for validation against observed temperatures, lapse rates and Positive Degree Days (PDDs) in each of the five years. Gardner et al. (2009) extrapolated temperatures from icefield summits to lower elevations, as reanalysis temperature-lapse rate relationships 
were stronger at higher elevations in that study; the same approach is followed here. Therefore, for validation, we compare observed temperatures at $500 \mathrm{~m}$ a.s.I., and corresponding PDDs, with those estimated by extrapolation from 1100 m a.s.I. using lapse rates as follows: (1) SALR, (2) a Variable Lapse Rate (VLR) using Gardner et al.'s (2009) proposed coefficients (VLR G09), (3) a second variable rate using the coefficients obtained from calibration at VestariHagafellsjökull (VLR). A constant lapse rate, determined as the mean of measured values, is not used for comparison, since its calculation would require sufficient lapse rate measurements to make its modeling redundant: the SALR is a more realistic comparator. Model errors are quantified in two further ways: Mean Error $(M E)$ reflects the overall tendency of modeled daily temperature, $T_{a}{ }^{*}$, to underestimate (if $M E$ is positive) or overestimate (if $M E$ is negative) measured temperature, $T_{a}$ :

$$
M E=\frac{\Sigma\left(T_{a}-T_{a}^{*}\right)}{d f}
$$

where $d f$ is degrees of freedom, determined as $N-P-1$, where $N$ is the number in the sample and $P$ is the number of predictors; Root Mean Square Error (RMSE) provides the standardized, mean model error for PDDs:

$$
R M S E=\sqrt{\frac{\Sigma\left(P D D-P D D^{*}\right)^{2}}{d f}}
$$

where $P D D^{*}$ is predicted PDDs.

The ensemble of regression coefficients and their validation statistics are presented in Table 5. To illustrate the outcome of the validation further, results 
from 2007 are also presented in Fig. 5, which shows daily mean modeled lapse rates and extrapolated $500 \mathrm{~m}$ a.s.I. temperature and cumulative PDDs for JuneSeptember of that year. All estimated coefficients are highly significant $(p<$ $0.001)$, and the standard errors of both slope $m$ and intercept $\beta$ range from $0.0068-0.0072$. It is clear that model $\beta$ is very consistent, ranging from $0.556-$ 0.570. In all validation years, modeled temperature ME and PDD RMSE are substantially reduced using the VLR model, compared with SALR predictions (Table 5): $T_{a} M E$ is reduced by $0.39^{\circ} \mathrm{C}$ on average, and $P D D R M S E$ by $4.5^{\circ} \mathrm{C}$ $\mathrm{d}^{-1}$ on average.

Neither VLR G09 or VLR capture the day-to-day variation in the observed lapse rate, but both track its trend reasonably (Fig. 5). For the early summer, VLR G09 actually provides a closer fit to the observed lapse-rate time series than VLR, which reflects the decision to include the more transitional month of September (Table 2; Section 4) in the calibration: had this been restricted to June-August, a lower lapse rate would have been determined $\left(0.53^{\circ} \mathrm{C} 100 \mathrm{~m}^{-1}\right.$, with slope -0.05), giving a closer VLR fit to the observed early-summer lapse rate. However, as melt typically occurs at this elevation in this location during September (Section 4), there is limited justification for excluding it. Nevertheless, the results of a Student's t-test on the observed lapse rate and $\operatorname{VLR}\left(\right.$ mean difference $=-0.018^{\circ} \mathrm{C} 100 \mathrm{~m}^{-1}, d f=116, t=-1.39, p=0.17$ ) indicates that the null hypothesis of no difference between series means cannot be rejected, so that VLR and the observed lapse rate are not significantly different overall. On the other hand, the same test applied to the observed lapse 
rate and VLR G09 (mean difference $=0.060^{\circ} \mathrm{C} 100 \mathrm{~m}^{-1}, d f=116, t=4.46, p<$ 0.0001 ) requires the null hypothesis to be rejected, so that these two series are indeed significantly different. This demonstrates, in particular, that VLR provides a better fit over the full June-September interval and that, in general, calibration of the Gardner et al. (2009) method for individual glaciers does yield quantifiable prediction improvements.

The advantages of using a variable lapse rate become apparent in the modeled values of temperature and cumulative PDDs (Table 5, Fig. 5). The observed June-September 2007 mean daily temperature at $500 \mathrm{~m}$ a.s.l. was $4.5 \pm 1.7^{\circ} \mathrm{C}$ : extrapolation from $1100 \mathrm{~m}$ a.s.I. with the SALR yields a corresponding value of $5.1 \pm 2.2^{\circ} \mathrm{C}\left(M E=-0.58^{\circ} \mathrm{C}\right)$; extrapolation with VLR G09 yields $4.1 \pm 1.8^{\circ} \mathrm{C}(M E=$ $\left.0.37^{\circ} \mathrm{C}\right)$; whereas extrapolation with VLR yields $4.6 \pm 1.9^{\circ} \mathrm{C}\left(M E=-0.11^{\circ} \mathrm{C}\right)$. The SALR particularly over-estimates temperatures by warming too quickly with decreasing elevation, but all estimated mean daily temperatures remain with \pm one standard deviation of the observed value. Values of cumulative PDDs over the course of the melt season offer more insight into the impacts of the different lapse rates. The observed June-September 2007 cumulative PDDs total at 500 m a.s.I. was $532^{\circ} \mathrm{C} d$ : the corresponding SALR estimate is $604^{\circ} \mathrm{C} \mathrm{d}$, a $14 \%$ over-estimate; VLR G09 yields $492^{\circ} \mathrm{C}$ d, a $7.4 \%$ under-estimate; whereas VLR yields $548^{\circ} \mathrm{C}$ d, a $3.0 \%$ over-estimate. Using Guðmundsson et al.'s (2009) degree-day factor for ice from Vestari-Hagafellsjökull, $0.0111 \mathrm{~m}$ w.e. ${ }^{\circ} \mathrm{C}^{-1} \mathrm{~d}^{-1}$, the SALR would generate $0.62 \mathrm{~m}$ w.e. excess melt compared to VLR, and 0.80 m w.e. compared to the observed PDD total. 


\section{Discussion}

Near-surface temperature variability is low in June, July and August at low elevations on Vestari-Hagafellsjökull, as indicated both by consistent mean monthly values from different calendar years (Fig. 4(A), Table 1) and by small monthly standard deviations (Fig. 4(B), Table 1). This is consistent with results from elsewhere (e.g. Arendt and Sharp, 1999; Hanna et al., 2005; Klok et al., 2005; Marshall et al., 2007; Gardner and Sharp, 2009) and largely explained by the fixed temperature $\left(0^{\circ} \mathrm{C}\right)$ of melting snow or ice surfaces. The same effect is certainly observed at high elevations also (Fig. 4(C)-(D), Table 1), although to a slightly lesser extent, as the diurnal and seasonal duration of melting is shorter compared to lower elevations. Following Denby et al. (2002), Gardner et al. (2009) explain this effect in terms of the increasing sensitivity of glacier nearsurface temperatures to changes in free-atmosphere temperatures with elevation. Free-atmosphere temperatures naturally vary more than the fixed $\left(0^{\circ} \mathrm{C}\right)$ temperature of a melting glacier surface, which is most characteristic of low elevations: free-atmosphere temperature increases here instead drive a sensible heat flux that contributes to total melt energy, suppressing vertical temperature gradients (Greuell and Böhm, 1998). On the other hand, nearsurface temperatures will increase more at higher elevations in response to free-atmosphere temperature increases, as their surfaces remain sub-freezing for greater durations. Therefore, near-surface temperatures increase faster at higher elevations in response to free-atmosphere temperature increases, and lapse rates are relatively subdued. 
The same explanation (lower near-surface temperature sensitivity to freeatmosphere temperature change in the presence of melting) accounts for the negative relationship between free-atmosphere temperature, represented both here and in Gardner et al. (2009) by $750 \mathrm{hPa}$ reanalysis temperature, and nearsurface lapse rate. This relationship was not significant every year at VestariHagafellsjökull (Table 4), although this was from spring-autumn data only, rather than year-round data. Such a relationship suggests a link between synoptic weather conditions and lapse rate, as has previously been recognized (e.g. Alt 1987; Braun and Hock, 2004; Gardner and Sharp 2007; Marshall et al. 2007). However, this link has proven difficult to capture statistically to date. Marshall et al. (2007) found no clear, statistical relationship between lapse rates and synoptic conditions in a multi-year dataset, but did identify recurrent patterns in monthly analyses. In particular, the steepness of the lapse rate during summer was inversely correlated with atmospheric pressure anomalies; this relationship broke down during winter. There is a distinct seasonal cycle of atmospheric pressure in Iceland, with a winter minimum (Jónsson and Hanna, 2007). Relatively stable, high-pressure summer conditions over VestariHagafellsjökull have been shown to correspond with lower monthly lapse rates than in spring or autumn (Section 5). This broadly inverse relationship between atmospheric pressure anomalies and lapse rate, at least over the springautumn part of the year, is consistent with the explanation of lapse rates during melt periods decreasing in response to free-atmosphere temperature increase, outlined above. However, further research in a wider range of glacierized 
environments is required to validate these interpretations - VestariHagafellsjökull is in a much lower-latitude, milder, less continental climate setting than the Canadian high-Arctic icefields examined by Marshall et al. (2007) and Gardner et al. (2009).

Relative to the SALR, estimates of cumulative PDDs, determined from nearsurface temperatures extrapolated from a high- to a low-elevation site on the surface of Vestari-Hagafellsjökull, are significantly improved by using a modeled, variable lapse rate which is a function of standardized anomalies in $750 \mathrm{hPa}$ temperature, derived from ERA-Interim climatology (Fig. 5). Moreover, the model coefficients are very stable over the five-year period examined here (Table 5). This suggests that, given the ready availability of reanalysis data and the simplicity of the modelling approach of Gardner et al. (2009), improved melt/mass-balance modelling results (whether from temperature-index or energy-balance approaches) may be obtained with a combination of inland, high-elevation AWS and reanalysis data, than with low-elevation/coastal AWS data and the SALR. Benefits are most likely to be realized in milder climate settings where temperatures are frequently close to $0^{\circ} \mathrm{C}$, both for precipitation type, and for the occurrence and amount of melting: extrapolation of lowelevation AWS temperatures with the SALR would lead to systematic underestimation of temperatures and PDDs at high elevations.

A further corollary of the lower melt-season, near-surface temperature sensitivity to free-atmosphere temperature change, and the consequent 
negative near-surface lapse rate/free-atmosphere temperature relationship, is that lower lapse rates can be expected under a warming climate (Gardner et al., 2009). This results from the increase in free-air temperatures, the earlier expansion of glacier melt to higher elevations, and therefore increased glacier area with a fixed $0^{\circ} \mathrm{C}$ temperature for a longer duration. This effectively places an upper limit on glacier near-surface temperature sensitivity to temperature change in the free atmosphere. Under these conditions, extrapolation of temperatures to higher elevations inland with present lapse rates would tend to over-estimate temperatures in the upper reaches of ice masses, and therefore over-estimate ablation in melt models. It is therefore unlikely to become less important to collect in-situ glacier meteorological data, not only to quantify temperatures and detect changes, but also to quantify and detect changes in their spatio-temporal variability, even as reanalysis data open up new tools for their modeling.

\section{Conclusions}

Melt-season (June-September), near-surface lapse rates, determined from five years' AWS temperature data, average $0.57^{\circ} \mathrm{C} 100 \mathrm{~m}^{-1}$ at VestariHagafellsjökull, compared to $0.70^{\circ} \mathrm{C} 100 \mathrm{~m}^{-1}$ for non-melt-season months (spring and autumn). Non-melt-season lapse rates are therefore very similar to the SALR, but melt season lapse rates are somewhat depressed: this is consistent with a low near-surface temperature sensitivity to free-atmosphere temperature change in the presence of melting. This result contributes to a body of work that has established that lapse rates over glaciers vary seasonally, 
and that melt season lapse rates are often lower than the SALR (e.g. Greuell and Böhm, 1998; Braun and Hock 2004; Steffen et al. 2004; Hanna et al. 2005; Marshall et al. 2007; Gardner et al., 2009). However, the lack of a simple, effective method for modeling variable lapse rates has, to date, generally led to a continued dependence on the SALR for implementing the spatial distribution of temperatures for melt and mass-balance models. Nevertheless, the observed lapse rate at Vestari-Hagafellsjökull for the validation year of 2007 was successfully modeled as a function of standardized anomalies in freeatmosphere temperature, represented by the $750 \mathrm{hPa}$ temperature from ERAInterim climatology, following the method of Gardner et al. (2009). The mean modeled lapse rate is not significantly different from the observed mean, and reduces over-estimation of cumulative melt season PDDs by $11 \%$, compared to the SALR, equating to $0.62 \mathrm{~m}$ w.e. ice melt with a plausible degree-day factor. ERA-Interim data therefore appear to offer a good representation of freeatmosphere temperature variability over the studied glacier. The effectiveness of the model implies a synoptic control over lapse rates, which has been suggested already, but remains to be explained fully. Reduced monthly lapse rates over Vestari-Hagafellsjökull coincide with relatively stable, high-pressure summer conditions, suggesting a broadly inverse relationship between atmospheric pressure anomalies and lapse rate (cf. Marshall et al., 2007), which is consistent with lapse rates declining during melt periods in response to free-atmosphere temperature increase. An explanatory framework for lapse-rate variability over glaciers has thus begun to emerge. 


\section{Acknowledgements}

Funding from NERC award NER/B/S/2001/00851 and from Royal Society awards RG062190 and TG092060 is gratefully acknowledged. The comments of two anonymous authors led to substantial improvements to the manuscript. 


\section{References}

Alt, BE. 1987. Developing synoptic analogs for extreme mass balance conditions on Queen Elizabeth Island ice caps. Journal of Climate and Applied Meteorology 26(12), 1605-1623.

Arendt, A, Sharp, M. 1999. Energy balance measurements on a Canadian high Arctic glacier and their implications for mass balance modelling. Interactions Between the Cryosphere, Climate and Greenhouse Gases (Proceedings of IUGG 99 Symposium HS2, Birmingham, July 1999). IAHS Publ. 256, 165172.

Björnsson, H, Pálsson, F, Haraldsson, HH. 2002. Mass Balance of Vatnajökull (1991-2001) and Langjökull (1996-2001), Iceland. Jökull 51, 75-78.

Braun, M, Hock, R. 2004. Spatially distributed surface energy balance and ablation modelling on the ice cap of King George Island (Antarctica). Global and Planetary Change 42(1-4), 45-48.

de Woul, M, Hock, R, Braun, M, Thorsteinsson, T, Johanneson, T, Halldorsdottir, S. 2006. Firn layer impact on glacial runoff: A case study at Hofsjökull, Iceland. Hydrological Processes 20, 2171-2185.

Denby, B, Greuell, W, Oerlemans, J. 2002. Simulating the Greenland atmospheric boundary layer. Part II: Energy balance and climate sensitivity. Tellus 54A, 529-541.

ECMWF. 2006. Newsletter No. 110 - Winter 2006/07. European Centre for Medium-range Weather Forecasts: Reading, UK.

ECMWF. 2007. Newsletter No. 111 - Spring 2007. European Centre for Medium-range Weather Forecasts: Reading, UK. 
ECMWF. 2008. Newsletter No. 115 - Spring 2008. European Centre for Medium-range Weather Forecasts: Reading, UK.

Gardner, AS, Sharp, M. 2007. Influence of the Arctic circumpolar vortex on the mass balance of Canadian high Arctic glaciers. Journal of Climate 20, 4586-4598.

Gardner, AS, Sharp, M. 2009. Sensitivity of net mass-balance estimates to near-surface temperature lapse rates when employing the degree-day method to estimate glacier melt. Annals of Glaciology 50, 80-86.

Gardner, AS., Sharp, MJ, Koerner, RM, Labine, C, Boon, S, Marshall, SJ, Burgess, DO, Lewis, D. 2009. Near-surface temperature lapse rates over Arctic glaciers and their implications for temperature downscaling. Journal of Climate 22, 4281-4298.

Glover, RW. 1999. Influence of spatial resolution and treatment of orography on GCM estimates of the surface mass balance of the Greenland Ice Sheet. Journal of Climate 12, 551-563.

Greuell, W, Böhm, R. 1998. 2 m temperatures along melting mid-latitude glaciers, and implications for the sensitivity of the mass balance to variations in temperature. Journal of Glaciology 44(146), 9-20.

Greuell, W, Knap, W, Smeets, P. 1997. Elevational changes in meteorological variables along a midlatitude glacier during summer. Journal of Geophysical Research 102, 25,941-25,954.

Guðmundsson, S, Björnsson, H, Pálsson, F, Haraldsson, HH. 2009. Comparison of energy balance and degree-day models of summer ablation on the Langjökull ice cap, SW-Iceland. Jökull 59, 1-18. 
Hanna, E, Jónsson, T, Box, JE. 2004. An analysis of Icelandic climate since the nineteenth century. International Journal of Climatology 24, 1193-1210.

Hanna, E, Huybrechts, P, Janssens, I, Cappelen, J, Steffen, K, Stephens, A. 2005. Runoff and mass balance of the Greenland ice sheet: 1958-2003. Journal of Geophysical Research 110(D13), D13108. DOI:

10.1029/2004JD005641.

Jóhanneson, T, Sigurdsson, O, Laumann, T, Kennett, M. 1995. Degree-day glacier mass-balance modeling with applications to glaciers in Iceland, Norway and Greenland. Journal of Glaciology 41, 345-358.

Jónsdóttir, JF. 2008. A runoff map based on numerically simulated precipitation and a projection of future runoff in Iceland. Hydrological Sciences Journal 53(1), 100-111.

Jónsson, T, Hanna, E. 2007. A new day-to-day pressure variability index as a proxy of Icelandic storminess and complement to the North Atlantic Oscillation index 1823-2005. Meteorologische Zeitschrift 16, 25-36.

Klok, EJ, Nolan, M, Van Den Broeke, MR. 2005. Analysis of meteorological data and the surface energy balance of McCall Glacier, Alaska, USA. Journal of Glaciology 51(174), 451-461.

Konya, K, Hock, R, Naruse, R. 2007. Temperature lapse rates and surface energy balance at Storglaciären, northern Sweden. Glacier Mass Balance Changes and Meltwater Discharge (Proceedings of IAHS Assembly in Foz do Iguaçu, Brazil, 2005). IAHS Publ. 318, 186-194.

Marshall, SJ, Sharp, MJ, Burgess, DO, Anslow, FS. 2007. Near-surfacetemperature lapse rates on the Prince of Wales Icefield, Ellesmere Island, 
Canada: implications for regional downscaling of temperature. International Journal of Climatology 27(3), 385-398.

Pope, A. 2009. Recent Changes to Langjökull Icecap, Iceland: An investigation integrating airborne LiDAR and satellite imagery. M.Phil. Thesis: University of Cambridge.

Seidel, DJ, Free, M. 2003. Comparison of lower-tropospheric temperature climatologies and trends at low and high elevation radiosonde sites. Climatic Change 59, 53-74.

Sigurðsson, F. 1990. Groundwater from glacial areas in Iceland. Jökull 40, 119146.

Steffen, K, Ngheim, SV, Huff, R, Neumann, G. 2004. The melt anomaly of 2002 on the Greenland Ice Sheet from active and passive microwave satellite observations. Geophysical Research Letters 31(20), L20402. DOI: 10.1029/2004GL020444.

Thomas, RH, Abdalati, W, Frederick, E, Krabill, WB, Manizade, S, Steffen, K. 2003. Investigation of surface melting and dynamic thinning on Jakobshavn Isbræ, Greenland. Journal of Glaciology 49, 231-239.

WGMS. 2009. Glacier Mass Balance Bulletin No. 10 (2006-2007). Haeberli, W, Gärtner-Roer, I, Hoelzle, M, Paul, F and Zemp, M (eds.), ICSU(WDS)/IUGG(IACS)/UNEP/UNESCO/WMO, World Glacier Monitoring Service: Zurich. 


\section{Figure Captions}

Figure 1. (A) Langjökull (subset of SPOT image GES 08-024, acquired 19/08/2004), with inset showing location within Iceland; the position of panel (B) is indicated. (B) Vestari-Hagafellsjökull, contours of elevation in $\mathrm{m}$ a.s.I. The locations of AWS discussed in the text are indicated.

Figure 2. Near-surface temperature time series at 500 and $1100 \mathrm{~m}$ a.s.I. on Vestari-Hagafellsjökull, and 750 hPa temperature from ERA-Interim climatology, for 2003-7 (6-hourly data). The vertical scale is identical on all panels.

Figure 3. Near-surface lapse-rate time series from Vestari-Hagafellsjökull, for 2003-7 (6-hourly data). The dashed line is the SALR $\left(0.65^{\circ} \mathrm{C} 100 \mathrm{~m}^{-1}\right)$. The vertical scale is identical on all panels.

Figure 4. Mean monthly temperature and temperature standard deviation at 500 and $1100 \mathrm{~m}$ a.s.l. (circled symbols are from 600 or $1000 \mathrm{~m}$ a.s.l. instead when these are not available: Table 1), and mean monthly lapse rate and lapse-rate standard deviation, for 2003-2007.

Figure 5. Validation of the Variable Lapse-Rate (VLR) model for the 2007 melt season (mean daily data): observed and estimated lapse rates, temperatures and cumulative Positive Degree-Days (PDDs). Each panel shows values derived from observation, from extrapolation using the Saturated Adiabtaic Lapse Rate (SALR, $0.65^{\circ} \mathrm{C} 100 \mathrm{~m}^{-1}$ ), the VLR model using recommended coefficients from Gardner et al. (2009) (VLR G09), and the VLR model calibrated for Vestari-Hagafellsjökull from 2003-6 data. 


\section{Tables}

Table 1. Mean monthly, near-surface air temperatures $\left(T_{a}\right)$ at the lowermost (500 m unless indicated by ${ }^{\dagger}$, in which case $T_{a}$ is from $600 \mathrm{~m}$ ) and uppermost (1100 $\mathrm{m}$ unless indicated $\mathrm{by}^{\dagger}$, in which case $T_{a}$ is from $1000 \mathrm{~m}$ ) AWS on Vestari-Hagafellsjökull. The error term $\sigma$ is the standard deviation. Only months for which sufficient data are available to generate lapse-rate values (Table 2) are included. $n$ is the number of 6-hourly temperature measurements available in a given month; the asterisk denotes when all potential measurements are available and have been used to determine descriptive statistics.

\begin{tabular}{|c|c|c|c|c|c|}
\hline Lower & $\begin{array}{c}2003 \\
T_{a} \pm \sigma,{ }^{\circ} \mathrm{C}(n)\end{array}$ & $\begin{array}{c}2004 \\
T_{a} \pm \sigma,{ }^{\circ} \mathrm{C}(n)\end{array}$ & $\begin{array}{c}2005 \\
T_{a} \pm \sigma,{ }^{\circ} \mathrm{C}(n)\end{array}$ & $\begin{array}{c}2006 \\
T_{a} \pm \sigma,{ }^{\circ} \mathrm{C}(n)\end{array}$ & $\begin{array}{c}2007 \\
T_{a} \pm \sigma,{ }^{\circ} \mathrm{C}(n)\end{array}$ \\
\hline April & $0.74 \pm 1.5(23)$ & $-0.17 \pm 2.7\left(120^{\star}\right)^{\dagger}$ & No data & $-4.1 \pm 3.4(115)^{\dagger}$ & $-3.1 \pm 4.6(113)^{\dagger}$ \\
\hline May & $1.0 \pm 3.4\left(124^{*}\right)$ & $3.0 \pm 2.4(93)$ & $1.1 \pm 2.7(89)$ & $-0.19 \pm 3.2(59)$ & $0.7 \pm 2.6\left(124^{*}\right)$ \\
\hline June & $4.7 \pm 1.2\left(120^{\star}\right)$ & $4.3 \pm 1.3\left(120^{*}\right)$ & $4.6 \pm 1.5\left(120^{*}\right)$ & $4.4 \pm 1.7\left(120^{*}\right)$ & $4.7 \pm 1.2\left(120^{*}\right)$ \\
\hline July & $5.5 \pm 1.4\left(124^{\star}\right)$ & $5.6 \pm 1.5\left(124^{*}\right)$ & $5.8 \pm 1.6\left(124^{\star}\right)$ & $5.2 \pm 1.4\left(124^{*}\right)$ & $5.4 \pm 1.2\left(124^{*}\right)$ \\
\hline Aug. & $6.3 \pm 1.5\left(124^{*}\right)$ & $5.9 \pm 2.2\left(124^{*}\right)$ & $4.3 \pm 1.7\left(124^{\star}\right)$ & $5.5 \pm 1.4\left(124^{*}\right)$ & $4.9 \pm 1.5\left(124^{*}\right)$ \\
\hline Sept. & $3.2 \pm 3.5\left(120^{\star}\right)$ & $4.1 \pm 1.6\left(120^{*}\right)$ & $1.4 \pm 2.7\left(120^{\star}\right)$ & $5.1 \pm 1.6\left(120^{*}\right)$ & $3.0 \pm 2.8\left(120^{*}\right)$ \\
\hline Oct. & $1.4 \pm 3.1(91)$ & $1.4 \pm 3.4(90)$ & $-1.1 \pm 3.0(54)$ & $0.96 \pm 3.5\left(124^{*}\right)$ & $1.3 \pm 3.7\left(124^{*}\right)$ \\
\hline Upper & $\begin{array}{c}2003 \\
T_{a} \pm \sigma,{ }^{\circ} \mathrm{C}(n)\end{array}$ & $\begin{array}{c}2004 \\
T_{a} \pm \sigma,{ }^{\circ} \mathrm{C}(n)\end{array}$ & $\begin{array}{c}2005 \\
T_{a} \pm \sigma,{ }^{\circ} \mathrm{C}(n)\end{array}$ & $\begin{array}{c}2006 \\
T_{a} \pm \sigma,{ }^{\circ} \mathrm{C}(n)\end{array}$ & $\begin{array}{c}2007 \\
T_{a} \pm \sigma,{ }^{\circ} \mathrm{C}(n)\end{array}$ \\
\hline April & $-2.6 \pm 3.5\left(120^{*}\right)^{\dagger}$ & No data & No data & No data & No data \\
\hline May & $-3.1 \pm 4.5\left(124^{*}\right)$ & $-0.49 \pm 3.3(91)$ & $-3.1 \pm 4.0(87)$ & $-4.8 \pm 3.6(59)$ & $-3.6 \pm 3.4\left(124^{*}\right)$ \\
\hline June & $1.8 \pm 1.0\left(120^{*}\right)$ & $1.3 \pm 1.6\left(120^{*}\right)$ & $1.3 \pm 1.9\left(120^{*}\right)$ & $0.60 \pm 1.8\left(120^{\star}\right)$ & $1.8 \pm 1.2\left(120^{*}\right)$ \\
\hline July & $2.5 \pm 1.1\left(124^{*}\right)$ & $2.5 \pm 1.4\left(124^{*}\right)$ & $2.8 \pm 1.8\left(124^{*}\right)$ & $1.9 \pm 1.6\left(124^{*}\right)$ & $2.6 \pm 1.3\left(124^{*}\right)$ \\
\hline Aug. & $3.4 \pm 1.7\left(124^{*}\right)$ & $2.5 \pm 2.3\left(124^{\star}\right)$ & $0.9 \pm 2.1\left(124^{*}\right)$ & $2.3 \pm 1.7\left(124^{*}\right)$ & $1.3 \pm 1.5\left(124^{*}\right)$ \\
\hline Sept. & $-1.1 \pm 3.9\left(120^{*}\right)$ & $0.62 \pm 2.2(55)$ & $-3.0 \pm 3.3\left(120^{*}\right)$ & $1.2 \pm 1.8\left(120^{*}\right)$ & $-1.5 \pm 3.2(100)$ \\
\hline Oct. & $-2.2 \pm 4.0(79)$ & No data & $-5.3 \pm 3.6(48)$ & $-1.4 \pm 3.0(71)$ & No data \\
\hline
\end{tabular}


Table 2. Mean monthly lapse rates $(\beta)$ from near-surface temperature time series (Table 1). The error term $\sigma$ is the standard deviation. Between one-four AWS operated on the glacier at any one time; where at least two were operating, the temperature at the highest-elevation AWS was subtracted from that at the lowest-elevation AWS to obtain the lapse rate. $\mathrm{n}$ is the number of paired, 6-hourly temperature measurements used to determine the lapse rate in a given month; the asterisk denotes when all potential measurements are available and have been used.

\begin{tabular}{|c|c|c|c|c|c|}
\hline & $\begin{array}{c}2003 \beta \pm \sigma, \\
{ }^{\circ} \mathrm{C} 100 \mathrm{~m}^{-1}(n)\end{array}$ & $\begin{array}{c}2004 \beta \pm \sigma, \\
{ }^{\circ} \mathrm{C} 100 \mathrm{~m}^{-1}(n)\end{array}$ & $\begin{array}{c}2005 \beta \pm \sigma, \\
{ }^{\circ} \mathrm{C} 100 \mathrm{~m}^{-1}(n)\end{array}$ & $\begin{array}{c}2006 \beta \pm \sigma, \\
{ }^{\circ} \mathrm{C} 100 \mathrm{~m}^{-1}(n)\end{array}$ & $\begin{array}{c}2007 \beta \pm \sigma, \\
{ }^{\circ} \mathrm{C} 100 \mathrm{~m}^{-1}(n)\end{array}$ \\
\hline April & $0.81 \pm 0.21(23)$ & No data & No data & No data & No data \\
\hline May & $0.69 \pm 0.30\left(124^{*}\right)$ & $0.58 \pm 0.25(91)$ & $0.70 \pm 0.35(87)$ & $0.77 \pm 0.19(59)$ & $0.72 \pm 0.25\left(124^{*}\right)$ \\
\hline June & $0.48 \pm 0.19\left(120^{*}\right)$ & $0.51 \pm 0.20\left(120^{*}\right)$ & $0.54 \pm 0.23\left(120^{*}\right)$ & $0.63 \pm 0.23\left(120^{*}\right)$ & $0.48 \pm 0.21\left(120^{*}\right)$ \\
\hline July & $0.49 \pm 0.19\left(124^{*}\right)$ & $0.52 \pm 0.23\left(124^{*}\right)$ & $0.49 \pm 0.28\left(124^{*}\right)$ & $0.55 \pm 0.21\left(124^{*}\right)$ & $0.46 \pm 0.20\left(124^{*}\right)$ \\
\hline Aug. & $0.49 \pm 0.29\left(124^{\star}\right)$ & $0.57 \pm 0.22\left(124^{*}\right)$ & $0.57 \pm 0.21\left(124^{*}\right)$ & $0.54 \pm 0.23\left(124^{*}\right)$ & $0.60 \pm 0.21\left(124^{*}\right)$ \\
\hline Sept. & $0.71 \pm 0.26\left(120^{*}\right)$ & $0.68 \pm 0.19(55)$ & $0.72 \pm 0.20\left(120^{*}\right)$ & $0.65 \pm 0.21\left(120^{*}\right)$ & $0.70 \pm 0.20(100)$ \\
\hline Oct. & $0.67 \pm 0.25(79)$ & No data & $0.73 \pm 0.20(48)$ & $0.63 \pm 0.30(71)$ & No data \\
\hline
\end{tabular}


Table. 3. Detrended temperature correlations between AWS data at three elevations on the glacier surface, and ERA-Interim data at three pressure levels (6-hourly data). All are highly significant $(p<0.001)$. The tabulated values are the Pearson Product-Moment Correlation coefficients. A further AWS at $1000 \mathrm{~m}$ a.s.I. in 2003 (only) yielded similarly-significant correlations of 0.69-0.87. n.d. denotes no AWS data available for correlation.

\begin{tabular}{|c|c|c|c|c|c|c|}
\hline & \multicolumn{3}{|c|}{ AWS data } & \multicolumn{3}{|c|}{ ERA-Interim data } \\
\hline & $\begin{array}{c}500 \mathrm{~m} \\
\text { a.s.l. }\end{array}$ & $\begin{array}{l}600 \mathrm{~m} \\
\text { a.s.l. }\end{array}$ & $\begin{array}{c}1100 \mathrm{~m} \\
\text { a.s.l. }\end{array}$ & $800 \mathrm{hPa}$ & $750 \mathrm{hPa}$ & $700 \mathrm{hPa}$ \\
\hline \multirow{5}{*}{$\begin{array}{l}\dot{\dot{p}} \\
\dot{0} \\
\text { É } \\
\dot{0}\end{array}$} & \multirow{5}{*}{-} & 2003: 0.95 & 2003: 0.89 & 2003: 0.78 & 2003: 0.75 & 2003: 0.70 \\
\hline & & 2004: 0.65 & 2004: 0.81 & 2004: 0.68 & 2004: 0.62 & 2004: 0.57 \\
\hline & & 2005: n.d. & 2005: 0.83 & 2005: 0.73 & 2005: 0.72 & 2005: 0.70 \\
\hline & & 2006: 0.74 & 2006: 0.74 & 2006: 0.75 & 2006: 0.72 & 2006: 0.69 \\
\hline & & 2007: 0.76 & 2007: 0.80 & 2007: 0.69 & 2007: 0.67 & 2007: 0.66 \\
\hline \multirow{5}{*}{$\begin{array}{l}\dot{D} \\
\dot{0} \\
\varepsilon \\
8 \\
8\end{array}$} & 2003: 0.95 & & 2003: 0.92 & 2003: 0.85 & 2003: 0.82 & 2003: 0.78 \\
\hline & 2004: 0.65 & & 2004: 0.63 & 2004: 0.79 & 2004: 0.72 & 2004: 0.66 \\
\hline & 2005: n.d. & - & 2005: n.d. & 2005: n.d. & 2005: n.d. & 2005: n.d. \\
\hline & 2006: 0.74 & & 2006: 0.70 & 2006: 0.73 & 2006: 0.68 & 2006: 0.63 \\
\hline & 2007: 0.76 & & 2007: 0.69 & 2007: 0.70 & 2007: 0.72 & 2007: 0.72 \\
\hline \multirow{5}{*}{$\begin{array}{l}\dot{\bar{p}} \\
\dot{\sigma} \\
E \\
\dot{8} \\
\dot{\sigma}\end{array}$} & 2003: 0.89 & 2003: 0.92 & \multirow{5}{*}{-} & 2003: 0.82 & 2003: 0.79 & 2003: 0.74 \\
\hline & 2004: 0.81 & 2004: 0.63 & & 2004: 0.78 & 2004: 0.75 & $2004: 0.73$ \\
\hline & 2005: 0.83 & 2005: n.d. & & 2005: 0.77 & 2005: 0.74 & 2005: 0.71 \\
\hline & 2006: 0.74 & 2006: 0.70 & & 2006: 0.67 & 2006: 0.62 & 2006: 0.58 \\
\hline & 2007: 0.80 & 2007: 0.69 & & 2007: 0.71 & 2007: 0.69 & 2007: 0.66 \\
\hline
\end{tabular}


Table 4. Pearson Product-Moment Correlation coefficients ( $r$, plus two-tailed critical value, $r_{\text {crit }}$, for $\left.p<0.05\right)$ for $750 \mathrm{hPa}$ temperatures and lapse rates (monthly mean data). Correlations in 2004 and 2007 are not significant; all others are significant ( $p$ indicated), and negative.

\begin{tabular}{lccccc}
\hline & $\mathbf{2 0 0 3}$ & $\mathbf{2 0 0 4}$ & $\mathbf{2 0 0 5}$ & $\mathbf{2 0 0 6}$ & $\mathbf{2 0 0 7}$ \\
\hline $\boldsymbol{r}$ & -0.84 & -0.10 & -0.97 & -0.85 & -0.37 \\
$\boldsymbol{r}_{\text {crit }}$ & 0.75 & 0.88 & 0.81 & 0.81 & 0.81 \\
$\boldsymbol{t}$ & -3.44 & -0.17 & -8.29 & -3.27 & -0.80 \\
$\boldsymbol{p}$ & 0.018 & $>0.50$ & 0.001 & 0.031 & 0.468 \\
\hline
\end{tabular}


Table 5. Validation results for variable lapse-rate (VLR) models, regressing near-surface lapse rate on standardized anomalies of ERA-Interim $750 \mathrm{hPa}$ temperature. Individual models are calibrated with June-September data from four of the five years 2003-7, and validated against the remaining year's data (so data from 2003, 2004, 2005 and 2006 are combined to calibrate a model which is validated with 2007 data, for example). The model coefficients are best-fit slope $(m)$ and mean June-September lapse rate $(\beta$, intercept): all are highly significant $(p<0.001)$. Model performance is quantified by comparing VLR predictions of mean, June-September, near-surface temperature $\left(T_{a}\right)$ and cumulative Positive Degree-Days $\left(\sum P D D\right)$ at 500 m a.s.l., based on applying the modelled lapse rate to $T_{a}$ at $1100 \mathrm{~m}$ a.s.I., with measured $(M)$ and Saturated Adiabatic Lapse Rate-derived (SALR) values, respectively. ME is the Mean Error and RMSE the Root Mean Squared Error of predicted $T_{a}$ and $P D D$.

\begin{tabular}{ccccccc}
\hline $\begin{array}{c}\text { Validation } \\
\text { year }\end{array}$ & $\boldsymbol{\beta}$ & $\boldsymbol{m}$ & $\begin{array}{c}\text { Mean } \boldsymbol{T}_{a} \\
\text { M, SALR, VLR }\end{array}$ & $\begin{array}{c}\text { ME } \boldsymbol{T}_{a} \\
\text { SALR, VLR }\end{array}$ & $\begin{array}{c}\sum P D D \\
\text { M, SALR, VLR }\end{array}$ & $\begin{array}{c}\text { RMSE PDD } \\
\text { SALR, VLR }\end{array}$ \\
\hline $\mathbf{2 0 0 3}$ & 0.570 & -0.069 & $4.9,5.6,5.1$ & $-0.69,-0.20$ & $612,702,640$ & $8.2,2.6$ \\
$\mathbf{2 0 0 4}$ & 0.565 & -0.081 & $5.0,5.8,5.3$ & $-0.59,-0.06$ & $553,615,560$ & $6.0,0.70$ \\
$\mathbf{2 0 0 5}$ & 0.559 & -0.058 & $4.0,4.5,3.9$ & $-0.43,0.12$ & $507,568,501$ & $5.6,0.58$ \\
$\mathbf{2 0 0 6}$ & 0.556 & -0.073 & $5.1,5.4,4.8$ & $-0.35,0.22$ & $616,659,590$ & $3.9,2.4$ \\
$\mathbf{2 0 0 7}$ & 0.566 & -0.069 & $4.5,5.1,4.6$ & $-0.58,-0.11$ & $532,604,548$ & $6.8,1.5$ \\
\hline
\end{tabular}




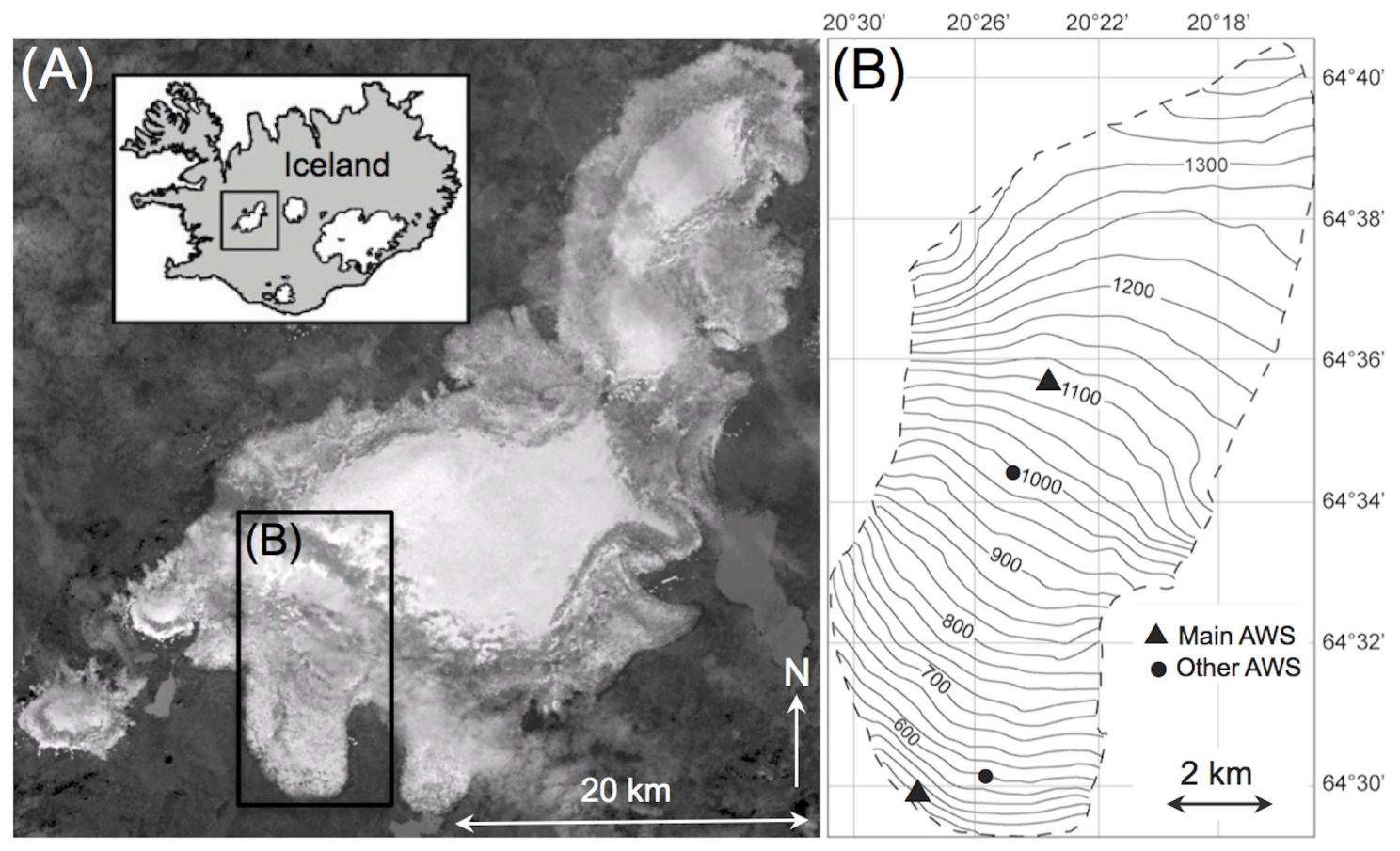

Figure 1. (A) Langjökull (subset of SPOT image GES 08-024, acquired 19/08/2004), with inset showing location within Iceland; the position of panel (B) is indicated. (B) Vestari-Hagafellsjökull, contours of elevation in $\mathrm{m}$ a.s.l. The locations of AWS discussed in the text are indicated. 

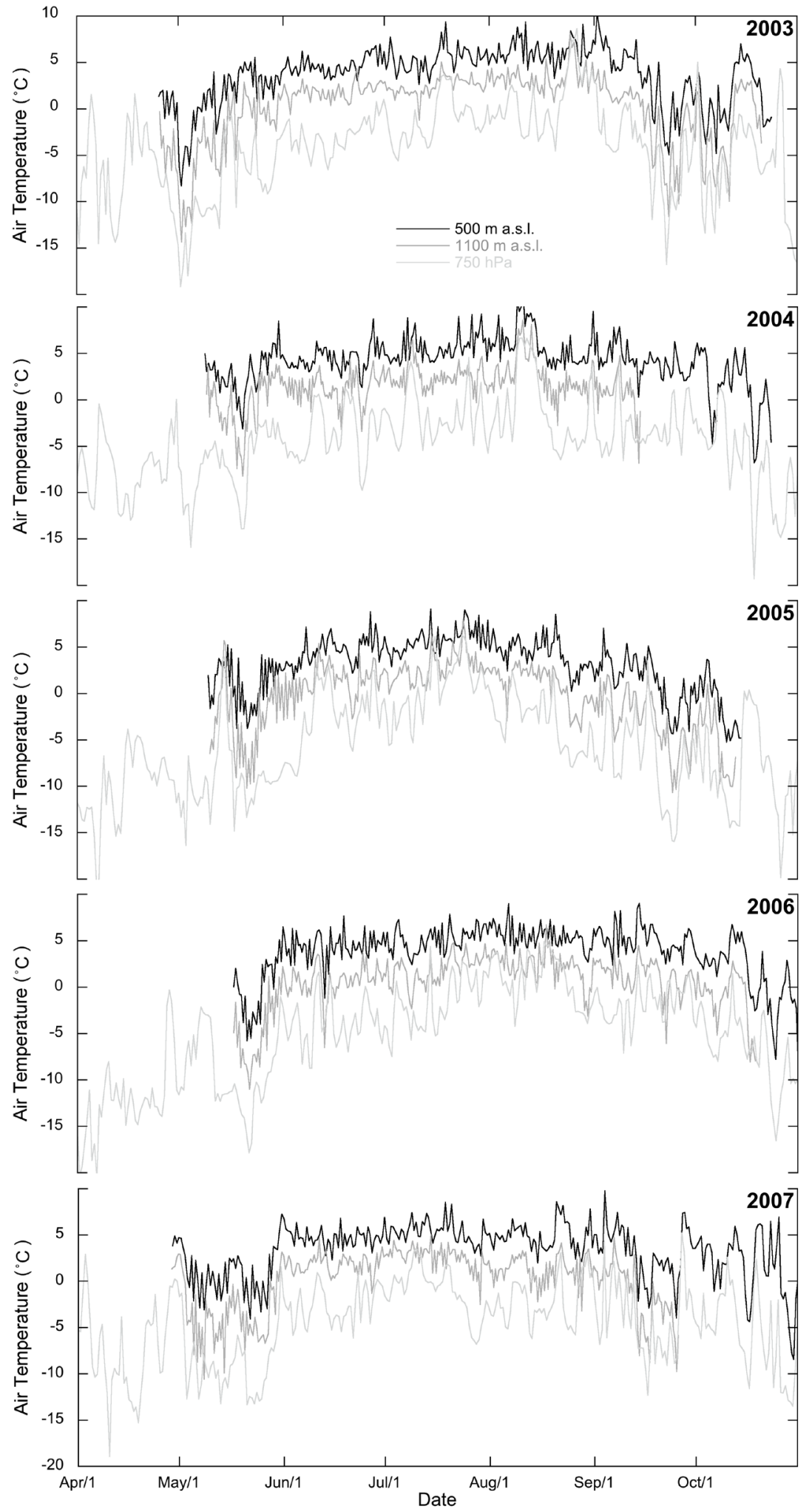

Figure 2. Near-surface temperature time series at 500 and $1100 \mathrm{~m}$ a.s.l. on Vestari-Hagafellsjökull, and $750 \mathrm{hPa}$ temperature from ERA-Interim climatology, for 2003-7 (6-hourly data). The vertical scale is identical on all panels. 

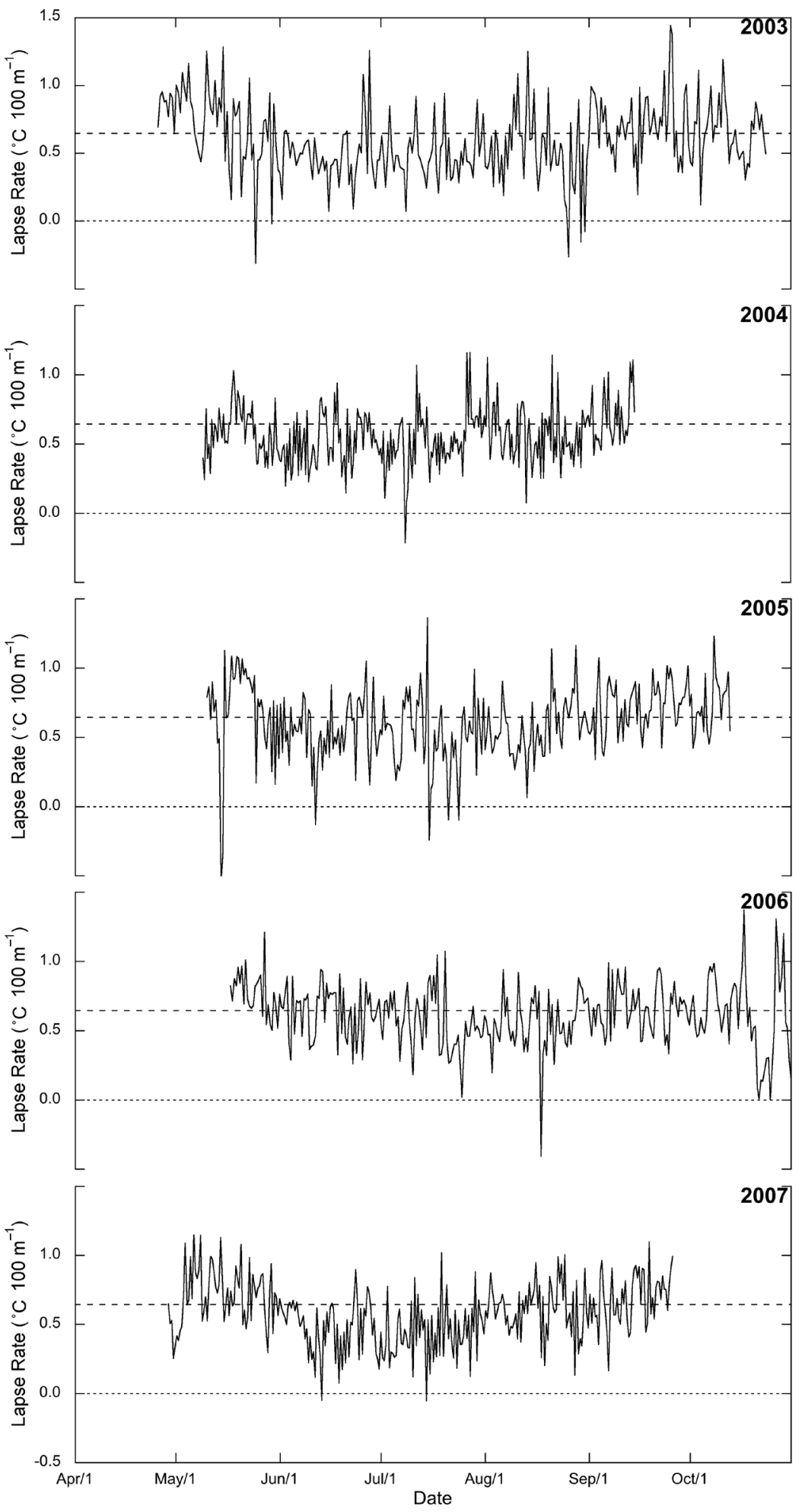

Figure 3. Near-surface lapse-rate time series from Vestari-Hagafellsjökull, for 2003-7 (6-hourly data). The dashed line is the SALR $\left(0.65^{\circ} \mathrm{C} 100 \mathrm{~m}^{-1}\right)$. The vertical scale is identical on all panels. 

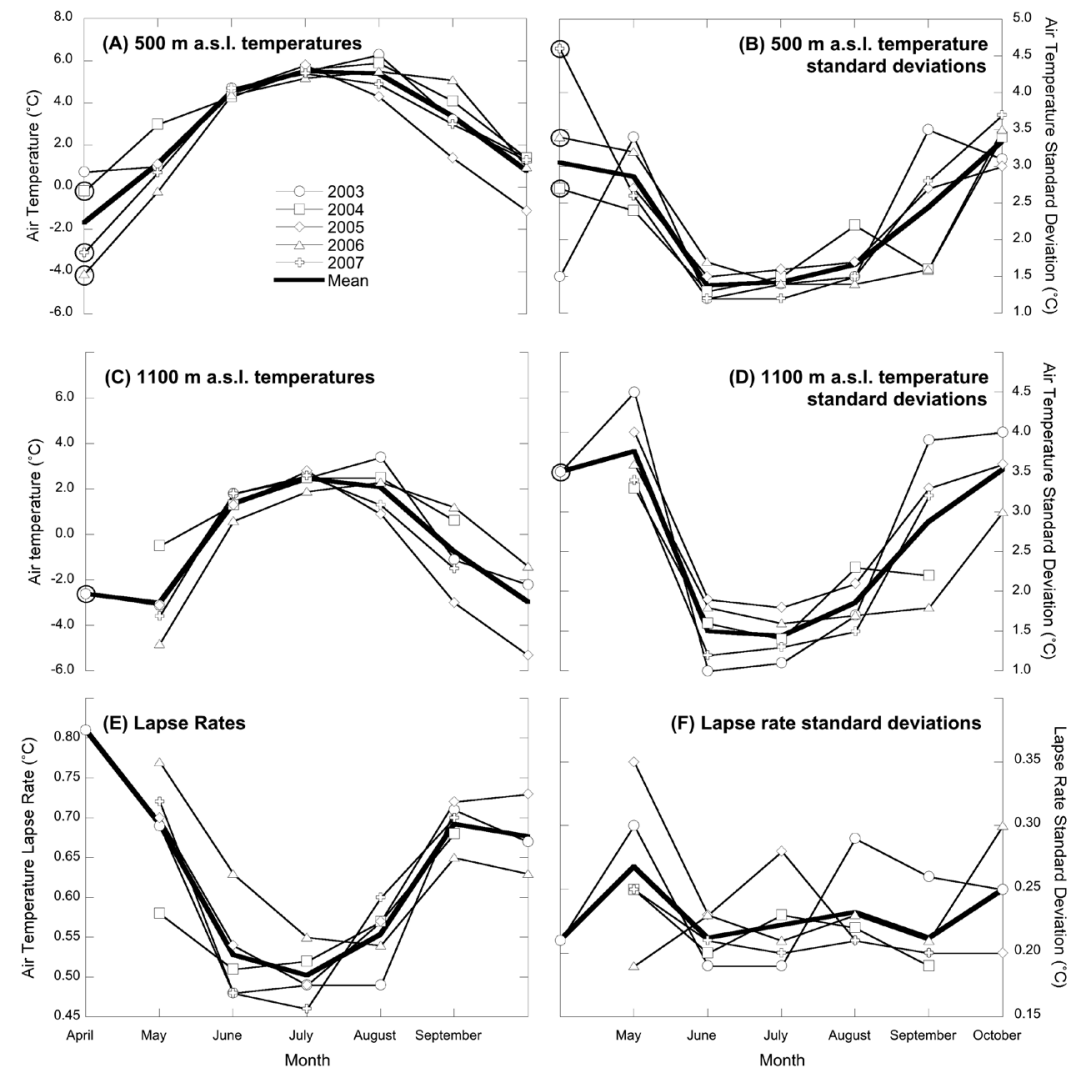

Figure 4. Mean monthly temperature and temperature standard deviation at 500 and $1100 \mathrm{~m}$ a.s.l. (circled symbols are from 600 or $1000 \mathrm{~m}$ a.s.l. instead when these are not available: Table 1), and mean monthly lapse rate and lapse-rate standard deviation, for 2003-2007. 


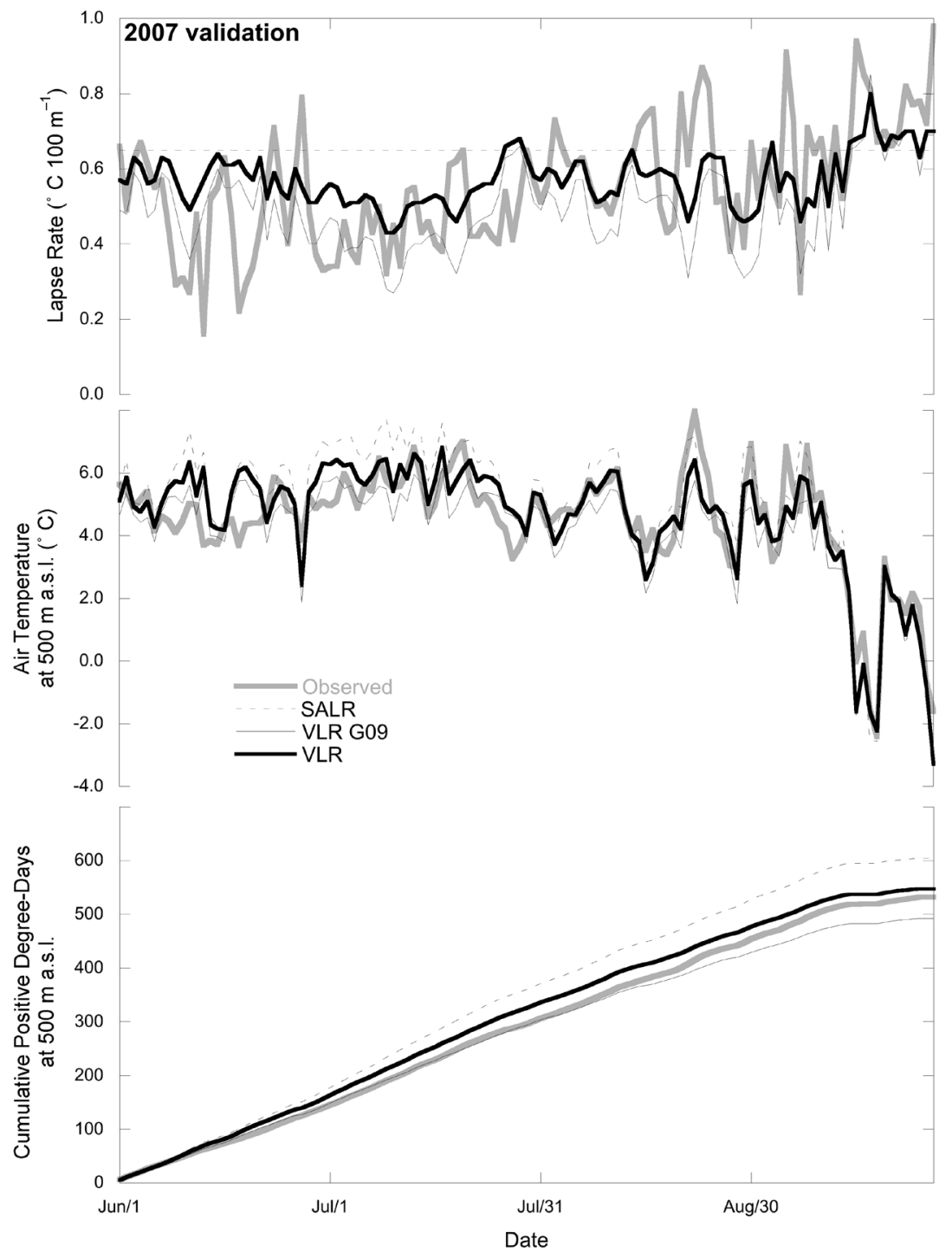

Figure 5. Validation of the Variable Lapse-Rate (VLR) model for the 2007 melt season (mean daily data): observed and estimated lapse rates, temperatures and cumulative Positive Degree-Days (PDDs). Each panel shows values derived from observation, from extrapolation using the Saturated Adiabtaic Lapse Rate (SALR, $0.65^{\circ} \mathrm{C} 100 \mathrm{~m}^{-1}$ ), the VLR model using recommended coefficients from Gardner et al. (2009) (VLR G09), and the VLR model calibrated for Vestari-Hagafellsjökull from 2003-6 data. 